\title{
Women Entrepreneurship in Informal Sector of the Economy
}

\author{
Mamo Esayas Ambe \\ Lecturer, Department of Economics, Wolaita Sodo University, P.O.Box 138
}

\begin{abstract}
The role played by the existence of dynamic as well as vibrant entrepreneurship skill in general and women entrepreneurship in particular has been recognized as potential tools of addressing several macroeconomic as well as microeconomic problems in which the society experienced in Ethiopia. This study has been carried on with the objective of investigating the role of women entrepreneurship in informal sector of the economy in misraq badewacho woreda where substantial women have been carrying on several potentially important informal sector economic activities so as to improve their day to day living conditions. the study involved 80 randomly selected women enerprenures engaged in different activities in the study area and both primary as well as secondary data has been used in order to carry on deep rooted investigation of the role played by the sector to economic growth and to identify factors impeding their operation which is associated with economic, social, institutional, political as well as institutional problems. Deep rooted descriptive analysis has been employed to achieve intended objective of the study . the investigation found that the activities of women entrepreneurship in informal sector would provide access to ob opportunities which in turn provide income opportunities as well as capacity to satisfy basic needs of their households . the study identified factors responsible for poor performance of the activity such as lack of market information, lack of working place, lack of developed skill, experiences and level of education, license requirement for their activity and associated bureaucratic procedure and lack of working capital for further expansion of their activity. The study recommends concerned bodies to create fertile legal, institutional as well as political environment capable of boosting women entrepreneurship in the Ethiopia.
\end{abstract}

DOI: $10.7176 / \mathrm{JCSD} / 45-01$

\section{CHAPTER ONE}

\subsection{Background of the Study}

Entrepreneurship is one of the main economic sources of individual's wellbeing. It also generates investment opportunities for new industries. In most developing country such as Ethiopia where sizeable proportion of its population lives under absolute poverty the role played by enterpreurs is becoming crucial in boosting economic growth and reducing poverty. In 2005 out of the total population $38.9 \%$ of them lives in absolute poverty which is characterized by socio- economic situation such as by low level of economic growth, high population increase rural to urban migration and political unrest.

Even though Women account for half of the entire population; they are at the bottom of the ladder in terms of employment, education and economic status, that means the potentials appear to be suppresses owing to them persisting major constrains that interred the participation of women on economic activities or access to the resource. Another problem is relates to access productive resource which characterizes women's incomes like lack of funding possibilities and adequate access to credit. The majority of the female labor force tends to be concentrate in micro-income generating activities that are predominantly informal and provide only the last resort for the maintenance of subsistence life in both urban and rural settings (ILO, 2009)

Women Enterpreurship has unparalleled role to contribute for the growth and development of developing as well as developed countries due to the fact that it can serve as the home of better innovation and technology,source of employment, source of generating income opportunities that is essential to minimize the income gap that prevailed between the rich and the poor .even though women account significant portion of the whole population in Ethiopia,

\subsection{Statement of the Problem}

The main difficulties that challenge developing countries, like Ethiopia is improving the problem of women entrepreneur who engages in informal trade sector. Women entrepreneurs in informal trade sector were a serious aspect in misraq badawach woreda. One of the reasons for these might be problems of women entrepreneurs in indirect trade sectors. This is supported by different empirical evidence. For example, Gemechis (2007) and ILO (2009) stressed that entrepreneurs are surrounded by a number of challenges. These force entrepreneurs in informal trade sectors not to contribute a lot to the poverty reduction of the town, region and the country as a whole. Gametes (2007) and ILO (2009).

Even though women entrepreneurs in informal trade sectors account the greatest proportion of total entrepreneurs in the country as a whole and in misraq badewacho woreda in particular, they are being challenged by several actors in their day to day endeavors .the combined effect of the existence of several bottleneck has been serving as potential cause of low performance in the study area. 


\subsection{Basic research question}

$>$ What are the factors that affect the success of women entrepreneur in informal trade sector?

$>$ What are the socio-economic statuses of women in informal trade sector operations?

\subsection{Objectives of the study}

\subsubsection{General objective}

The general objective of the study is to investigate the factors affecting the success of women entrepreneurs in the informal trade sector in the case of misraq badeacho woreda .

\subsubsection{Specific objective}

$>$ To identify the factors that affects women entrepreneurs in misraq badewacho woreda

$>$ To assess socio- economic status of women in informal trade operators.

\subsection{Significance of the study}

The study was expected to generate valuable information on women entrepreneurs involved in informal trade sector that would assist policy makers in designing appropriate policies for intervention. It will also be important to transfer women entrepreneurs involved in informal trade sector in to formal trade sectors. This is because formal trade sector have greater contribution for economic development than informal trade sector. The finding of the study was also provided important policy intervention and strategies that focuses on poverty alleviation and sustainable development of the country. The result of this study were also believed to serve as reference documents for other researchers to embark on studies of the same or related kinds in other part of the country.

\subsection{Scope of the study}

The study is delimited to assess the role of women entrepreneurship in informal sector of the economy for economic growth and development endeavor in misraq bedewacho woreda of hadiya zone. the study involved women engaged in sevral informal sector activities in 2009. E.C.

\section{CHAPTER TWO}

\section{Review of Related Literature}

\subsection{An overview to entrepreneurship}

As globalization reshapes the international economic landscape and technological change creates greater uncertainty in the world economy, the dynamism of entrepreneurship is believed to be able to help to meet the new economic, social and environmental challenges. Governments increasingly consider entrepreneurship and innovation to be the cornerstones of a competitive national economy, and in most countries entrepreneurship policies are in fact closely connected to innovation policies, with which they share many characteristics and challenges. The dynamic process of new firm creation introduces and disperses innovative products, processes and organizational structures throughout the economy. Entrepreneurship objectives and policies nevertheless differ considerably among countries, owing to different policy needs and diverse perspectives on what is meant by entrepreneurship. (Schumpeter 2005)

In some countries, entrepreneurship is linked to regional development programs and the creation of new firms is stimulated to boost employment and output in depressed regions. In others, entrepreneurship is a key element of strategies designed to facilitate the participation of certain target groups, such as women or minorities, in the economy. Some countries simply seek to increase firm creation as such, while others set out to support high-growth firms. While many countries are making serious efforts to support entrepreneurship, results appear to vary. Countries want to understand the determinants of and obstacles to entrepreneurship, and they need to analyze the effectiveness of different policy approaches (p.13)

The lack of internationally comparable empirical evidence has however constrained our understanding of entrepreneurship and many questions remain unanswered. Ultimately, policy making must be guided, as far as possible, by evidence and facts.(P. 9)

\subsubsection{Meaning and definitions of entrepreneurship}

There is no agreement among authors regarding the definitions of Entrepreneurship. Different authors tried to define it in different manners. This doesn't mean however that there are no common elements among authors. Some of the definitions are given below:

According to Ponstadt (1998) Entrepreneurship is the dynamic process of creating incremental wealth. This wealth is created by individuals who assume the major risks in terms of equity, time and/or career commitments of providing values for some product or service. The product or service may/may not be new or unique but value must be infused by the entrepreneur by securing and allocating the necessary skills and resources (p.9)

Furthermore, Timmons (1989) defined it in such a way that Entrepreneurship is the process of creating and building something of value from practically nothing. That is, it is the process of creating or seizing an opportunity and pursuing it regardless of the resources currently controlled. It involves the definition, creation 
and distribution of values and benefits to individuals, groups, organizations and society. Entrepreneurship is very rarely a get rich-quick proposition (not short term); rather it is one of building long term value and durable cash flow streams (p.29)

In addition, Hisrich (2005) defined Entrepreneurship is the process of creating something new with value by devoting the necessary time and effort, assuming the accompanying financial, psychic, and social risks, and receiving the resulting rewards of monetary and personal satisfaction and independence (p.2).

From the definitions given above, it is possible to conclude that in almost all of the definitions of entrepreneurship, there is agreement about a kind of behavior that includes: (1) initiative taking, (2) the organizing and reorganizing of social and economic mechanisms to turn resources and situations to practical account, (3) the acceptance of risk or failure.

\subsubsection{The benefits of entrepreneurship}

It is abundantly clear that entrepreneurship is important for economic growth, productivity, innovation and employment, and many countries have made entrepreneurship explicit policy priority. Entrepreneurial activities have been recognized as an important element in organizational and economic development, performance and wealth creation. According to World Bank (2007), Fox (2001) and Hisrich (2005) entrepreneurship has the following benefits.

$>$ Entrepreneurs are their own bosses. They make the decisions. They choose whom to do business with and what work they will do. They decide what hours to work, as well as what to pay and whether to take vacations.

$>$ Entrepreneurship offers a greater possibility of achieving significant financial rewards than working for someone else.

$>$ It provides the ability to be involved in the total operation of the business, from concept to design and creation, from sales to business operations and customer response.

$>$ It offers the prestige of being the person in charge.

$>$ It gives an individual the opportunity to build equity, which can be kept, sold, or passed on to the next generation.

$>$ Entrepreneurship creates an opportunity for a person to make a contribution. Most new entrepreneurs help the local economy. A few-through their innovations - contribute to society as a whole.

$>$ It is a catalyst for economic change and growth.Entrepreneurship increase per capita output and income .By doing so it involves initiating and constituting change in the structure of business and society. As a result entrepreneurship contribute a lot in increasing countries output and productivity

$>$ Entrepreneurship encourages innovation and creativity. It develops new products or service for the market to fulfill human needs. It also stimulates investment interest in the new ventures being created. Entrepreneurship through its process of innovation creates new investment of new ventures .More ventures being created, new jobs will be produced, thus reduce the unemployment rate. That will Creates and promotes wealth distribution. As explained above, entrepreneurism helps the economy by creating wealth for many individuals seeking business opportunities. Although this is not the number one reason individuals pursue entrepreneur activities, it plays a major role in our economy.

\section{CHAPTER THREE}

\section{METHODOLOGY}

\subsection{Source of data}

The data for this study was obtained mainly from primary data source and secondary data source.

\subsubsection{Primary data source}

The primary data was collected by a face to face personal interview and via distributing of questionnaires .

\subsubsection{Secondary data source}

The secondary data was also collected from different offices like central statistical and small, medium scale enterprise agency through relevant materials such as research documents, books, and internet.

\subsection{Sampling technique and Sampling Size}

In this study individual women entrepreneurs engaged in informal trade sector were the units of analysis. This study was used non- probability sampling technique which is the convenient sampling technique. Data will be collected from target population, since the number of kebles in the town 2 and the total number of population is50454 based of this information the researcher was selected three kebles. The selected kebles are lalo grebe ,licha and arencha kebeles.. Since random sampling technique is important to collect data from women entrepreneurs engaged in informal trade sectors who have no any list of recorded information like their living condition, Income level, profitability, marital status, level of formal education, nature of current business activity. Growth prospects of their business, socio cultural issues that affect their business operation and other related data. In addition to this the respondents also provide valuable information during face to face interview without any 
frightens to obtain reliable information. The total population in the study area is about 76543 from which the target population is 400 in order to select the sample respondents from the study; I want to use convenient sampling method to select 80 sample populations.

By using yamane formula ( 1967 )

$$
\begin{gathered}
\mathrm{n}=\mathrm{N} / 1+\mathrm{N}(\mathrm{e}) 2 \\
\text { Where } \mathrm{n}=\text { Sample size required } \\
\mathrm{N}=\text { Targeted total household populations } \\
\mathrm{e}=\text { Margin of error (Level of precision) } \\
\text { Then } \\
\mathrm{N}=400 \\
\mathrm{e}= \pm 10 \%=0.1 \\
\mathrm{n}=400 / 1+400(0.1) 2=400 / 1+400(0.01) \\
\mathrm{n}=400 / 5 \\
\mathrm{n}=\underline{\mathrm{80}} \text { is the required sample size }
\end{gathered}
$$

\subsection{Methods of Data Analysis}

Descriptive statistics was one of the techniques used to summarize information (data) collected from a sample. By applying descriptive statics such, as percentages, tables, frequency of appears ratio test. Descriptive statistics were computed and arranged in a way that allows one to quickly comprehend their meaning.

\section{CHAPTER FOUR}

\section{Result and Discussion}

4.1 Demographics of the women informal operators

\begin{tabular}{|c|c|c|c|c|c|c|}
\hline \multirow[b]{2}{*}{ Age category } & \multicolumn{2}{|c|}{ Female respondents } & \multicolumn{3}{|c|}{ Male respondents } & \multirow[b]{2}{*}{ Percent } \\
\hline & Frequency & Percentage & frequency & Percentage & Number & \\
\hline $10-20$ & 14 & 28 & 8 & 26.67 & 22 & 27.5 \\
\hline $21-30$ & 23 & 46 & 15 & 50 & 38 & 47.5 \\
\hline $31-40$ & 8 & 16 & 4 & 13.33 & 12 & 15 \\
\hline Above 40 & 5 & 10 & 3 & 10 & 8 & 10 \\
\hline Total & 50 & 100 & 30 & 100 & 80 & 100 \\
\hline
\end{tabular}

Table 4.1 The general background of respondents

\begin{tabular}{|l|l|l|}
\hline Sex & Number of respondents & Percent \\
\hline Male & 30 & 37.5 \\
\hline Female & 50 & 62.5 \\
\hline Total & 80 & 100 \\
\hline
\end{tabular}

Source: - own survey ( year 2009 E.C)

The above table shows that among the total respondents $37.5 \%$ are male and $62.5 \%$ are female. That means from 80 respondents, 50 are female respondents and 30 are male. These indicates that majority of the respondents are female. The survey result indicated that in table4.2 below, 47.5 percent of women entrepreneurs are in the age range of 21-30. In this age category women seek opportunities to secure better future and flexible decision.

Table 4.2: age distribution of respondents

Source: own survey 2009 EC

The above table indicates that most male and female respondents are aged between 21-30 years and the remaining are above the age of 31 and below 21 . These indicates that most of female and male respondents are in productive age, so these kinds of situation lead them into informal sectors where they get low income as salary and other traditional practice such as child/ early marriage practice on women when they have no job.

It is also showed that 27.5 percent of the respondents entrepreneur are young (less than 20 years of age) in which most of them are school dropouts who cannot get employed not only due to insufficient absorptive capacity of the economy but also the lack of marketable skill among them and 10 percent of the respondents are over 40 years of age in which these entrepreneur are most of the time seeking security (or risk averse activity) in their venture than participating in new activity.

\subsubsection{Marital status of sample respondents}

Marital status has its own distinct levels of social, cultural and economic responsibilities which affect individual women's participation in economic activities. Hence the rate of participation of single, married and widowed women is expected to differ significantly. 
Table 4.3 marital status of respondents

\begin{tabular}{lllllll}
\hline & \multicolumn{2}{l}{ Female respondents } & \multicolumn{2}{l}{ Male respondents } & \multicolumn{2}{l}{ Total respondents } \\
\hline Marital status & frequency & In percent & frequency & In percent & Frequency & Percent \\
Un married & 17 & 34 & 9 & 30 & 26 & 32.5 \\
Married & 9 & 18 & 5 & 16.67 & 14 & 17.5 \\
divorced & 5 & 10 & 3 & 10 & 8 & 10 \\
widowed & 19 & 38 & 13 & 43.33 & 32 & 40 \\
\multicolumn{1}{c}{ Total } & 50 & 100 & 30 & 100 & 80 & 100 \\
\hline
\end{tabular}

Source: own survey, 2009 E.C

The above table (table 4.3 ) shows that 9 male or $30 \%$ and 17 female or $34 \%$ respondents are un married. In addition 5 males and 9 female respondents are married. They represents $16.67 \%$ male and $18 \%$ female respectively. Among all respondents 3 male and 5 female respectively grouped at divorced. This represents $10 \%$ for both male and female. More over 13 male and 19 female respondents are categorized as widowed.

Concerning marital status in a whole ,the survey showed that about 32.5 percent of the interviewed are single 17.5 percent are married 10 percent are divorced 40 percent are widowed.

The relatively high percentage of single women operators in the survey could be an indicative of the high poor or unemployment in the city with young women resorting to informal activities .The same table indicated that married women are more likely to become entrepreneurs in order to support their families because of the responsibilities they shoulder as married women.

\subsubsection{Educational status of respondents}

General education imparts computational skills, which the entrepreneur applies in his/her transaction and it can also impart specific skills. Therefore, a well-designed education system is critical for woman to attract customers, make contractual agreement and negotiate on mutually beneficial basis. Yet the survey result revealed that $72.5 \%$ of the respondents have had formal education but the remaining $27.5 \%$ did not attend any schooling or formal education of these lucky to be at school $2.5 \%$ attended primary school (grade1-4), $17.5 \%$ junior secondary school grade (5-8), $27.5 \%$ reached Secondary school (9-12 grades), and $12.5 \%$ of the respondent had graduate from college and other institution. This is an agreement with the fact that the bulk of women Informal sector entrepreneurs come from the ranks of those who dropped out of school or never attended at all.

Table 4.4: Educational status of sample respondents

\begin{tabular}{lllllll}
\hline & Female respondents & Male & respondents & \multicolumn{2}{l}{ Total respondents } \\
Educational status & Frequency & percentage & frequency & percentage & Frequency & Percent \\
Illiterate & 14 & 28 & 8 & 14 & 22 & 27.5 \\
Reading and Writing & 6 & 12 & 4 & 6 & 10 & 12.5 \\
Grade 1-4 certificate & 1 & 2 & 1 & 1 & 2 & 2.5 \\
Grade 5-8 certificate & 9 & 18 & 5 & 9 & 14 & 17.5 \\
High school( 9-12) certificate & 13 & 26 & 9 & 13 & 22 & 27.5 \\
From College and above graduate & 7 & 14 & 3 & 7 & 10 & 12.5 \\
Total & 50 & 100 & 30 & 50 & 80 & 100 \\
\hline
\end{tabular}

Source: Own Survey 2009 E.C

The above table (table. 4.4) indicates that there is $14 \%$ male and $28 \%$ female respondents are illiterate. Among all respondents from grade 1-8, 10 female and 6 male respectively attended the primary education (1-8). This represents $20 \%$ of the female and $10 \%$ of the male respondents. More over 9 male and 13 female respondents attended the secondary education. This represents $13 \%$ male and 26 female respondents. Furthermore 3 male or $7 \%$ and 7 female or $14 \%$ respondents attended at the college.

\subsubsection{Family size of sample respondents}

The survey results showed that 57.5 percent of women entrepreneurs had the family size Category of 3-4, which seeks huge amount of money to satisfy basic necessities of those Family members and they entered into the informal business operation as means of Livelihood since they had no employed in any formal business operation.

Table 4.5 Family size of ample respondents

\begin{tabular}{lll}
\hline Family size category & Frequency & Percent \\
\hline $\mathbf{1 - 2}$ & 22 & 27.5 \\
$\mathbf{3 - 4}$ & 46 & 57.5 \\
Above 4 & 12 & 15 \\
Total & 80 & 100 \\
\hline
\end{tabular}

Source: Own survey 2009 E.C

It also indicated that $27.5 \%$ and $15 \%$ of women entrepreneurs have had a family size Category of 1-2 and above 4 respectively. The first category indicated that women Entrepreneurs were entered into the business 
either to sustain themselves or their Husband/child through informal business operation. The second category indicated that Women entrepreneurs entered into business operation for the purpose of satisfying Basic necessities of the large family members lie that of family size category of 3-4.

\subsection{Involvement of women in different informal business operation}

The survey result showed that 25 percent of women entrepreneurs were involved in the Business activity of selling fruits and vegetables, in which most of the customer uses, these goods for moral satisfaction for a repeating time.

Table4.7 Different informal business activities

\begin{tabular}{lll}
\hline Table of selling business & Frequency & Percent \\
\hline Cooked food & 14 & 17.5 \\
Fire wood and charcoal & 6 & 7.5 \\
Second and used cloth & 8 & 10 \\
Fruit and vegetable & 20 & 25 \\
Chaffier & 4 & 5 \\
Measuring human wait & 8 & 10 \\
Selling religious guide & 8 & 10 \\
Shoeshine & 8 & 10 \\
Making house hold material from grass & 4 & 5 \\
Total & 80 & 100 \\
\hline Source;own souce 2009 E.C
\end{tabular}

source ;own source 2009 E.C

It also showed that 17.5 percent of women entrepreneurs are concentric in the business activity of selling cooked food in which most of the people buy these product as a breakfast, a lunch and a dinner who had no welldefined place to prepare basic necessitate foods to sustain their life.

In addition to this the survey result indicated that 10 percent of women entrepreneurs are in the business activity of selling chaff, shoeshine, second used hand cloth and measuring human weight among these 10 present of respondents were involved in the selling of religious book. All this business was profitable but its main problem would be lack of start -up capital for women entrepreneurs who had no financial sources /credit services. The remaining women entrepreneurs are involved in selling activity of chaffier (5 percent)making house hold materials from grass (5 percent ) and selling fire wood and charcoal (7.5percent).

\section{3 source of start-up capital for entrepreneurs}

The survey result showed that the amount of start-up capital reported by the trader range from ETB 500 to ETB 2500. It also indicated that 40 percent of respondents source of capital was from own saving by which these entrepreneurs operate the business which out any leading of credit service from other persons.

This rewarded that they would generate large amount of profit as compared with other source of start-up capital, since they did not paid any interest rate for the capital, since they did not paid any interest rate for the capital that was used in the business operation and the mean value of own saving as a source of capital was ETB 97.94 as averagely calculated. Table4.8 Source of start-up

\begin{tabular}{lll}
\hline Major source of start-up capital & Frequency & Percent \\
\hline Own saving & 28 & 40 \\
Money lenders & 32 & 35 \\
Family loans & 16 & 20 \\
Assistance of relates/friend & 4 & 5 \\
From other source & & \\
Total & 80 & 100 \\
\hline
\end{tabular}

Source; own survey 2009 EC

The survey result also indicated that 35 percent of women entrepreneurs' major source of start-up capital was borrowed from money lenders. It also indicated that 20 and 5 percent of respondents reported that their main source of start-up capital was from family loans and assistance from relatives / friend / respectively. For these business operate they received their start-up capital and continue their business operation until they were self-owned. After that woman entrepreneurs returned the start-up capital back to the family and to the assistance friend.

\subsection{Major reasons for women to enter into the informal business}

The survey result indicated that $30 \%$ of the respondents were entered in to informal business operation for the reason of unemployment. To earn a living and being employed in a profitable business activity. Because living without a means of livelihood is very difficult and for this reason they were employed in the informal business 
operation. It also indicated that 17.5 present of women entrepreneurs entered in the informal business operations for the reason of dependence. Dependency is a situation by which people live on the shoulder of others. Women hate thus bad situation outliving and entered in to informal business operations.

Table 4.9: Major reasons to enter into informal trade.

\begin{tabular}{llllllll}
\hline & \multicolumn{2}{l}{ Male respondents } & \multicolumn{2}{l}{ Female respondents } & & \\
Reason & frequency & percentage & frequency & percentage & Frequency & Percent \\
Dependence & 6 & 20 & 8 & 16 & 14 & 17.5 \\
Un employment & 9 & 30 & 15 & 30 & 24 & 30 \\
Survival & 3 & 10 & 5 & 10 & 8 & 10 \\
New opportunity & 4 & 13.33 & 6 & 12 & 10 & 12.5 \\
Poverty & 4 & 13.33 & 8 & 16 & 12 & 15 \\
Supplementary income & 2 & 6.67 & 4 & 8 & 6 & 7.5 \\
Inadequate wage & 2 & 6.67 & 4 & 8 & 6 & 7.5 \\
Total & 30 & 100 & 50 & 100 & 80 & 100 \\
\hline
\end{tabular}

Source: own survey 2009 .E.C

The survey data also showed that 15 percent of women entrepreneurs entered in to the informal business operations for the reasons of poverty. This is subsistence way of life and they hope that informal business operation would permit us to get sufficient money to eradicate poverty and labeled with rich persons. In addition to thus points, the survey data indicated that 12.5 percent, of respondents are entered into new opportunity and 7.5 percent for supplementary income and 10 percent of the respondents enter in to in the informal business operation for the reason of survival. For supplementary income means to found additional income to the existing source of income and for new opportunity means creation of new business operation in the market place. The women also entered to get the business operation for the purpose of survive. The way by which women entrepreneurs are employed and survive in the Shone area.

\subsection{Major constraints of women entrepreneurs in informal trade sector}

The respondents were asked to name most important problem encountered in their business activity. The main problem cited by 47.5 percent of the sample respondent was lack of infrastructure. Because there are informal traders they have no specific or limited market place for the business activity. The second most important constraints was lack of finance which accounts 15 percent's higher percentage of respondents who are involved in selling non-food items reported that lack of capital was the major constraints since this business requires relatively higher capital like selling second and hand clothes and majoring human weights (digital balance) also a very small amount of capitals is requires to set up activities like use table vending, lack of capital is still the most important problem. In addition to these there are other category problems like education $(2.5$ percent), transport problem(2.5 percent), lack of training(2.5percent), sanitation problem(10\%),lack of time(10 percent), lack of acceptance as entrepreneurs(2.5percent)and wood and energy problem(7.5percent).

Table4.10 Reason of entering to informal trade

\begin{tabular}{lll}
\hline \multicolumn{1}{c}{ Constraints } & Frequency & Percent \\
\hline Lack of financé & 12 & 15 \\
\hline Lack of infrastructure & 38 & 47.5 \\
\hline Lack of education & 2 & 2.5 \\
Lack of training & 2 & 2.5 \\
Transport problem & 2 & 2.5 \\
Sanitation problem & 8 & 10 \\
\hline Lack of time & 8 & 10 \\
Lack of acceptance as entrepreneurs & 2 & 2.5 \\
\hline Wood and energy problem & 6 & 7.5 \\
\hline Total & 80 & 100 \\
\hline Sour:
\end{tabular}

Source: own survey 2009 EC

\section{CHAPTER FIVE}

\section{Conclusion and Recommendation \\ 5.1 Conclusion}

Given the economic situation prevailing in the country the informal sector will continue to play a greater role in improving peoples socio economic lives. The findings of the studies showed that mainly widowed and never married women entrepreneurs were involved in informal business operation largely. It also showed that women entrepreneurs who family members involved in the business operation of informal trade sector for the purpose of satisfying the basic necessities of those members of the family. 
The major factor that led the growth of the informal sector is the inability of the formal sector to absorb the ever-increasing labor force owning mainly to poor economic performance through time. It is also believed that the urban informal sector provide job opportunities for the majority of the urban labor force. The survey result revealed that young women entrepreneurs are involved in the business. This is because of the fact that most of the time young people seek to capture better means of income and being free from dependence. The study found that the majority of women entrepreneurs in informal trade sector concentrate on the selling of fruits and vegetables. Unlike other selling activities it does not require much capital and skills. It has been proved that most illiterates and school drop-out women entrepreneurs are concentrated in selling of fruits and vegetables in informal trade. Because they had no another choice to earn income or to get job opportunity. The study also proved that the major constraints of women entrepreneurs is lack of suitable market place, lack of infrastructure and source of start-up capital in large.

The research result released that the major reason that women entrepreneurs entered into informal business operation is unemployment and as it is shown in the empirical analysis the amount of labor supply has a significant effect on the earning level of women entrepreneurs.

\subsection{Recommendation}

Based on the finding of the study the following recommendation should need to be provided since Lack of suitable market place for women entrepreneurs in the informal trade sector has been identified as a major constraint for them and the government should alleviate this problem.

$>$ The government should provide important training skill for illiterate and school drop-out women, lack of suitable market place for women entrepreneurs involved in informal trade business operation around informal business operation and make them profitable in the market place; since they are mainly illiterate and school drop-outs.

$>$ It is highly recommended that the government should create job opportunity for unemployed women entrepreneurs as unemployment is a major reason that women to enter into informal trade sector.

$>$ It also recommended that the government should provide financial or credit service at lower interest rate for women entrepreneurs concentrated in informal trade sector as lack of finance is relatively the main constraint in their business operation

$>$ The government should provide critical emphases on informal trade sector like that of formal trade sector. Since informal trade sector also play significant role in the development of the country.

$>$ Last but not least recommendation is that their should be macroeconomic framework capable of creating good condition for informal sector operator of women entrepreneur in order to grow fast and contribute for the development of the economy at large

\section{REFERENCES}

Beavon.K.1989.informal ways: A window on informal Business in South Africa SBDC: Johannesburg Bullocks. 1994. women at work .London .Zed Books.

chen. A.M. JhabVala .R. And. Lund,F.(2001).supporting. Workers in the formal Economy: A policy Frame work papered for H.O Tasks force on the informal Economy.

Cross J.T.(1998). The informal sector Encyclopedia of political Economy htt://www.openaair.org.

CSA (2002).Central Statically Agency Informal sector Report -2003 www.CSA.org.

CSA (2002).Central Statically Agency census Report -2011 www.CSA.org

Eshetu, B. and Zeleke, W. (2008).Women entrepreneurship in micro, small and medium enterprises: The case of Ethiopia. Journal of international women's studies.Vol.10, pp.3-5)

Hatten,T.S. 1997. Small business Entrepreneurs ship beyond upper saddle River: Prentice Hall. International Labor Organization.(972). The informal sector.

ILO 1993. African Employment report (1992). The world Employ program.AA, Ethiopian.

ILO (1993).women in the informal sector and their access to micro finance,.paper prepared for the inter Union (IPU). Annual conference. Windhock. Numbia .2.11. April.

Gemechis Tefera (2007).Attitude Of College Students Towards Entrepreneurship: A Case Study of Addis Ababa University and Rift Valley University College. Addis Ababa, Ethiopia. Unpublished Thesis

Green, E., \& Cohen, L. (1995). Women's businesses: Are women entrepreneurs breaking

new ground or simply balancing the demands of 'women's work' in a new way? Journal of Gender Studies, 4 (3), 297-314.

Helms, M. (1997). Women and Entrepreneurship: The Appealing Alternative. Business Perspectives. Vol. 10, i1 (pp. 16-19). Gale Group - Information Integrity.

Hisrich, R.D. (2005), Entrepreneurship.7th Edition, Boston: McGraw Hill. Retrieved on 15-5-10 from http://www.csb.uncw.edu/people/rowej/classes/mba533old/MBA 533001 Class 6 Student.pdf.

ILO. (2006).Vulnerability and young women Entrepreneurs: A case study of Ethiopian Informal Economy. 


Geneva: International $\quad$ Labor $\quad$ Organization. $\quad$ Retrieved $\quad$ on $\quad$ 16-5-
10fromhttp://www.cartierwomensinitiative.com/docs/Ethiopian_women_entrepreneurs_ILO.pdf.

Kuchta. Helbling.C . (2000).Barriers of Participation. The in formal sector in Emarging Democracies. The world movement for democracies saopaula center for International Private Enterprise (CIPE).

Lioyed, M.R. and. Morn G.S.(2001). Local Economic Development in Rural Eastern CapeTown. Part Elizabeth: Vista University.

Mariucci. p.p(2001).jobs. Gender small Enterprise in Africa and Asia. Lessons Drawn from Bangladesh, the Philippines ,Tunisia and Zambia. SEED. Working paper No.18

OECD (2002). The Keys for Successful Women Entrepreneurs. The OECD Bologna Process, December 2002.

UNIDO .(2001). Women Entrepreneurship Development in Selected African Countries. 